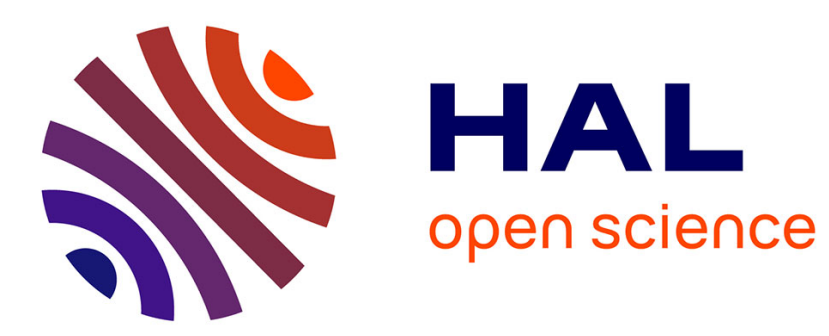

\title{
Epilepsies and neuronal plasticity: for better or for worse?
}

Yehezkel Ben-Ari

\section{To cite this version:}

Yehezkel Ben-Ari. Epilepsies and neuronal plasticity: for better or for worse?. Dialogues in Clinical Neuroscience, 2008, 10 (1), pp.17-27. inserm-00483486

\section{HAL Id: inserm-00483486 https://www.hal.inserm.fr/inserm-00483486}

Submitted on 14 May 2010

HAL is a multi-disciplinary open access archive for the deposit and dissemination of scientific research documents, whether they are published or not. The documents may come from teaching and research institutions in France or abroad, or from public or private research centers.
L'archive ouverte pluridisciplinaire HAL, est destinée au dépôt et à la diffusion de documents scientifiques de niveau recherche, publiés ou non, émanant des établissements d'enseignement et de recherche français ou étrangers, des laboratoires publics ou privés. 


\title{
Basic research
}

\section{Epilepsies and neuronal plasticity: for better or for worse?}

\author{
Yehezkel Ben-Ari, PhD
}

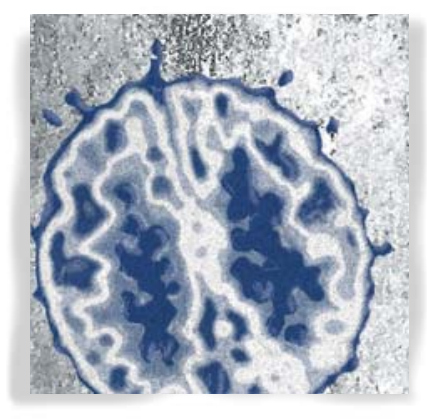

Extensive experimental investigations have confirmed that "seizures beget seizures." Thus, in adults, limbic seizures lead to cell loss, followed by the formation of novel excitatory synapses that contribute to generating further seizures. The triggering signal is an enhancement of synaptic efficacy, followed by a molecular cascade that triggers axonal sprouting. New synapses are aberrant, since they are formed in regions in which they are not present in controls. They also involve receptors that are not present in controls, and this facilitates the generation of seizures. Therefore, an aberrant form of reactive neuronal plasticity provides a substrate for the long-lasting sequelae of seizures. Since these events take place in brain structures involved in integrative and mnemonic functions, they will have an important impact. Reactive plasticity is documented for other insults and disorders, and may be the basis for the long-term progression of neurodegenerative disorders.

(c) 2008, LLS SAS

Dialogues Clin Neurosci. 2008;10:000-000.

Keywords: temporal lobe epilepsy; sprouting; novel synapse

Author affiliations: Director of Research, French Medical Research Council (INSERM); Director, Mediterranean Institute of Neurobiology (INMED), Marseille, France

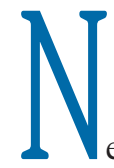

etworks are endowed with the capacity to generate a large repertoire of behaviorally relevant patterns and oscillations relying on the intrinsic properties of assemblies of interconnected neurons. These oscillations are not only involved in integrative programs, but also play an important role in the induction of long-lasting modifications of synapse efficacy ${ }^{1-9}$ Recurrent activation of synapses and interconnected networks leads to various forms of neuronal plasticity that constitute the main mechanisms on which networks rely to augment or reduce the response to incoming information. ${ }^{3,10}$ These mechanisms have been extensively investigated, relying on protocols that induce short- and long-term potentiation and depression of synaptic efficacy. ${ }^{11-14}$ They are usually triggered by a rise in $\left[\mathrm{Ca}^{2+}\right]_{i}$ that initiates a cascade of molecular events and more permanent changes associated with the formation of novel synapses. These mechanisms constitute the core of the modulation by activity and experience of network activity and the essence of memory processes. ${ }^{11-14}$

Epilepsies are associated with episodes of altered/enhanced activity, and therefore they are expected to also produce long-term alterations in synaptic efficacy and network reorganizations. Studies performed in the last 2 to 3 decades have shown that "seizures beget seizures," with a cascade of events triggered by seizures that transform a naive network into one that generates seizures..$^{15-20}$ The sequence starts with an inaugurating event/insult, followed by a cascade of molecular and biochemical events that produce the quasi-permanent shift. They culminate with a reactive

Address for correspondence: : Yehezkel Ben-Ari, Director, INSERM U29-INMED, Parc Scientifique de Luminy, BP 13, 13273 Marseille Cedex 09, France

(e-mail: ben-ari@inmed.univ-mrs.fr) 


\section{Basic research}

\section{Selected abbreviations and acronyms

$\begin{array}{ll}\text { AMPA } & \begin{array}{l}\alpha \text {-amino-3-hydroxy-5-methylisoxazole-4-propi- } \\ \text { onic acid }\end{array} \\ \text { EPSC } & \text { excitatory postsynaptic current } \\ \boldsymbol{G A B A} & \gamma \text {-aminobutyric acid } \\ \text { HFO } & \text { high-frequency oscillations } \\ \text { LTP } & \text { long-term potentiation } \\ \text { NMDA } & N \text {-methyl-D-aspartic acid }\end{array}$

plasticity associated with sprouting of axons and the formation of novel synapses that appear to play a central role in the generation of seizures. These novel synapses are aberrant, since they are formed on neurons that do not possess these inputs in naive conditions. They are also unique to epileptic tissues, as they use receptors and signals that do not operate in controls (reactive plasticity). These important features have several important fundamental and applied consequences.

This paper will discuss these issues, stress the similarities and differences between physiological and pathogenic forms of neuronal plasticity, and ask the following questions: Do seizures lead to similar alterations as episodes of enhanced activity engaged in memory processes? If not, how do they differ? Are physiologically relevant mechanisms altered to leave a trace of the original insult, leading to the pathogenic generation of abnormal patterns and their neurological correlates? Since alterations of neuronal activity are observed in other disorders, is reactive plasticity also involved in nonepileptic types of disorders? Finally, the general implications of these observations will be briefly discussed. Since seizures also induce long-lasting sequelae in developing brain structures, but by quite different means, the relationship between seizures and epilepsies in the developing brain will also be briefly addressed.

\section{The hippocampal circuitry: a target for studies on various forms of neuronal plasticity}

Most of our understanding of the mechanisms of neuronal plasticity and their link with seizures comes from studies devoted to the hippocampus. This "simple" cortical structure is composed of a principal layer-the pyramidal and granule cell layer-and molecular layers with basal and apical dendrites of principal neurons- the stratum oriens and stratum radiatum respectively. These principal neurons are excitatory, using glutamate as a transmitter with primarily $\alpha$-amino-3-hydroxy-5methylisoxazole-4-propionic acid (AMPA) receptors to generate the fast-acting excitatory postsynaptic currents (EPSCs). Powerful stimulation can also activate Nmethyl-D-aspartic acid (NMDA) receptors-a calciumpermeable receptor channel complex that is blocked in physiological conditions by $\mathrm{Mg}++$ ions in a voltagedependent manner. ${ }^{21}$ The increase in the intracellular concentration of calcium leads to a cascade of molecular events that will produce long-lasting quasi-permanent changes in synaptic efficacy, primarily by means of postsynaptic mechanisms. ${ }^{14,22}$ In addition, a plethora of inhibitory $\gamma$-aminobutyric acid-(GABA)ergic neurons and synapses provide a highly specific pattern of innervations that modulate neuronal excitability and thus control the entire network and the generation of behaviorally relevant oscillations.

The basic circuit is organized around a trisynaptic excitatory circuit, with a massive input originating in the entorhinal cortex that innervates the apical dendrites of the granule cells, followed by the axons of granule cells that establish giant mossy fiber synapses with the proximal segment of the CA3 pyramidal neurons and finally the axons of the latter-the Schaeffer collateral-that innervate the apical dendrites of CA1 pyramidal neurons. CA3 pyramidal neurons also send out an extensive network of recurrent collaterals that innervate via other CA3 pyramidal neurons, facilitating the generation of synchronized activities and seizures. The CA3 pyramidal system is amongst the brain regions the most susceptible to seizures, triggering events, and drugs, mostly because of an abundant excitatory recurrent collateral net of synapses between pyramidal neurons that will facilitate the emergence of synchronized activities.

\section{Physiological and pathological forms of long-term potentiation of synaptic efficacy}

High-frequency stimuli of synapses generate a long-term potentiation of synaptic transmission with long-lasting enhanced EPSCs. The induction is generated by an influx of calcium, mainly mediated by NMDA receptors, and the expression is mediated by a persistent increase in the density of AMPA receptors. ${ }^{13,14}$ In most protocols, NMDA receptors play an important role in the induction but not the expression of the augmented signals, ie, AMPA not NMDA receptor-mediated EPSCs are augmented by the 
protocol. Brief seizures produced for instance by brief applications of the powerful convulsive agent kainate (see below) also induce a long-term potentiation (LTP) of EPSCs..$^{20}$ Like physiological LTP, the induction of this process is mediated by the activation of NMDA receptors. However, the expression of this "epileptic LTP" also involves NMDA receptor-mediated EPSCs that are persistently facilitated. ${ }^{23,24}$ Thus, seizures produce long-lasting alterations of synapse efficacy, but the underlying mechanisms are different. Several mechanisms have been suggested to explain the persistent increase of NMDA receptor-mediated EPSCs, including alterations of regulating sites of the receptor channel complex..$^{23,24}$ Interestingly, other insults also produce long-term alterations of synaptic efficacy, including brief anoxic insults, suggesting that pathological forms of LTP may constitute a general mechanism involved in translating their deleterious sequelae into alterations of synapse efficacy. ${ }^{25,26}$ Therefore, episodes of augmented activity or other insults do lead to persistent changes of synaptic efficacy, somehow deviating physiological processes.

\section{Kainic acid: an analogue of glutamate that plays an important role in neuronal synchronizations}

Purified-form marine algae, kainic acid, is an analogue of glutamic acid that produces a long-lasting excitation of neurons via a subclass of glutamate receptors. ${ }^{27,28}$ These receptors are enriched, notably on mossy fiber synapses established on the proximal apical dendrites of CA3 pyramidal neurons (stratum lucidum).$^{19}$ More recent studies have shown kainate receptor-mediated synapses confirming their role in physiological conditions. Thus, "pure" kainate receptor-mediated EPSCs are recorded in CA3 pyramidal neurons. ${ }^{29,30}$ These EPSCs differ from AMPA receptor-mediated EPSCs by their longer kinetics and their smaller amplitude. In addition, mixed AMPA/kainate receptor-mediated EPSCs are also recorded, indicating that both receptor types are involved in mediating fast glutamatergic synaptic activity. Kainate receptors are also enriched on GABAergic interneurons, where they provide almost half the ongoing glutamatergic activity. ${ }^{29,31}$ A direct association between mossy fiber terminals and "kainatergic" synapses has also been shown, confirming the close relationship between kainate signaling and the CA3 mossy fiber terminals. ${ }^{29}$ Kainatergic postsynaptic currents (PSCs) have a slower and smaller amplitude than the conventional AMPA receptor-mediated currents, suggesting that they will play different tunes in the generation of synchronized oscillations.

Several subclasses of kainate receptors have been cloned, including the GluR5 subunits that are enriched on interneurons, and the GluR 6 subunits enriched on mossy fiber synapses. ${ }^{32-34}$ The GluR 6 subunits are enriched on mossy fiber terminals, and have been associated with seizures. The threshold for seizure generation is reduced in transgenic animals depleted of this subunit. ${ }^{17,35,36} \mathrm{On}$ the other hand, GluR 5 subunits are enriched on interneurons where they provide as much as half of the excitatory inputs. ${ }^{17,37}$ Therefore, kainate signaling will both facilitate paroxysmal activity by means of GluR 6 receptor-containing synapses, and prevent seizures by means of GluR 5 receptor-containing synapses and the augmented inhibition that they produce. ${ }^{31,38}$

\section{The kainate animal model generates a seizure and brain damage syndrome that mimics human temporal lobe epilepsies}

Systemic or intracerebral injections of kainate generate long-lasting limbic seizures, followed by a pattern of lesions in the hippocampus and other limbic structures. ${ }^{17,27,39,40}$ The electrographic pattern and the subsequent lesions have a distribution that is quite similar to that observed in patients suffering from temporal lobe epilepsy (TLE) with a preferential involvement of the CA3 and CA1 regions, GABAergic interneurons, and the pyriform cortex, as well as other limbic cortices and subcortical regions. The amygdala plays a central role in the sequence, as suggested by the powerful actions of very low concentrations of kainate injected in that region and the clinical and electrographic signs that imply the involvement of that structure (ref?). Extensive investigations clearly indicate that the neuronal cell loss is at least in part due to the excessive activation of certain glutamatergic fibers, and in particular the mossy fiber terminals that produce a lesion of the neurons that they innervate.

\section{From cell loss to neosynapse formation}

Neurons adjacent to, or even linked to, damaged neurons do not remain idle. Studies in the early 1970s had already shown that in the hippocampus, lesions of the perforant 


\section{Basic research}

pathway leads to a reorganization of other inputs, with aberrant connections being formed..$^{41}$ Sprouting after an episode of status epilepticus has been extensively illustrated with kainate and other models of seizures. In the early 1980s, studies relying on the unique feature of mossy fibers-the high density of zing-positive Timm stain and of high-affinity kainate receptors-showed that, after seizures, an additional band of mossy fiber terminals is formed (Figures 1 to 3 ). ${ }^{19,42-45}$ This has been extensively confirmed in a variety of animal models of epilepsies, and in human temporal lobe epileptics and other types of epilepsies. ${ }^{46}$ The formation of novel synapses was also shown by electron microscopy, relying on the unique features of mossy fiber terminals that form the largest complex of postsynaptic excrescences readily identified with certainty. ${ }^{47}$ Therefore, new synapses are formed after status epilepticus, and many of these synapses are aberrant, ie, present on target neurons that are not innervated by these neurons in naive networks.

Studies using molecular biology tools indicate that after a status epilepticus as many as 1000 genes are activated. ${ }^{48-51}$ These occur with a progressive time course-from immediate early genes to growth factors (hours after the event) to receptors and cell adhesion molecules days later, providing a likely scenario of molecular cascades

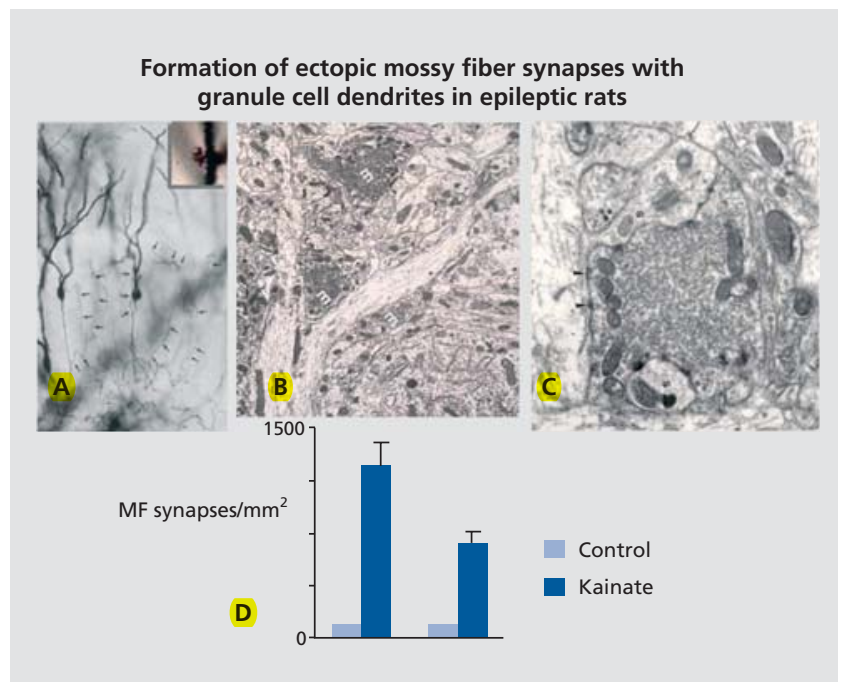

Figure 2. Electron microscopic identification of aberrant mossy fiber terminals on granule cells weeks after an inaugurating status. Note the formation of synapses in regions that are not innervated by mossy fibers in controls. These aberrant synapses have all the typical unique features of mossy fiber terminals, notably the large size and the enrichment in vesicles.

Reproduced from ref 45: Represa A, Pollard H, Moreau J, Ghilini G, Khrestchatisky M, Ben-Ari Y. Mossy fiber sprouting in epileptic rats is associated with a transient increased expression of alpha-tubulin. Neurosci Lett. 1993;156:149-152. Copyright (c) Elsevier Scientific Publishers Ireland 1993
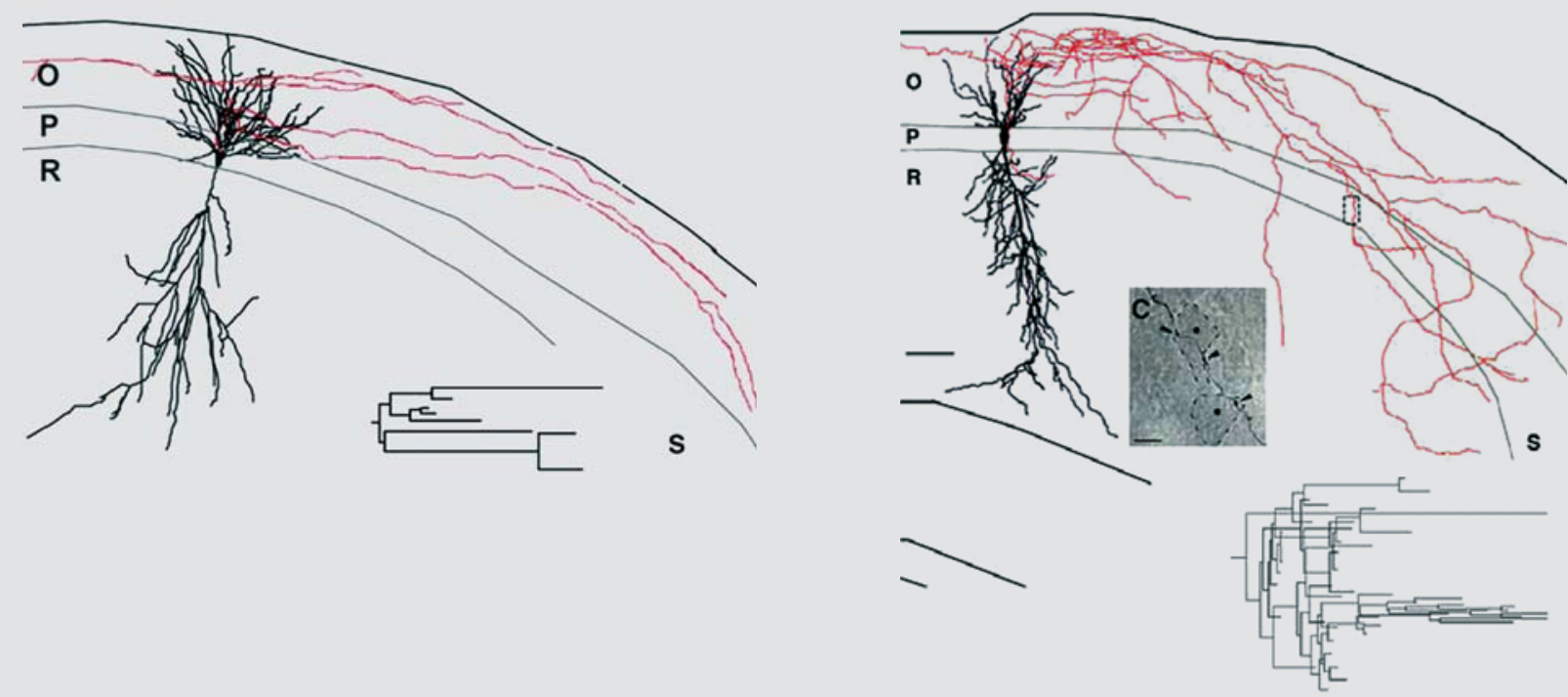

Figure 1. Sprouting of fibers in the hippocampus of epileptic rats. Morphological reconstruction of CA1 hippocampal neurons intracellularly injected with dyes weeks after an inaugurating status epilepticus. Note the extensive sprouting of axons, including to layers (the molecular layers) that are not innervated by pyramidal axons in controls. O, stratum oriens; P, stratum pyramidale; R: stratum radiatum; S, XXXXXX Reproduced from ref 44: Esclapez M, Hirsch JC, Ben Ari Y, Bernard C. Newly formed excitatory pathways provide a substrate for hyperexcitability in experimental temporal lobe epilepsy. J Comp Neurol. 1999;408:449-460. Copyright @ Wiley-Liss 1999 
set in motion by the episode of hyperactivity. The actual sprouting is most likely terminated within 1 to 2 weeks. The functionality of these novel synapses was confirmed with electrophysiological recordings. Thus, recordings of pyramidal neurons after a status epilepticus showed an increased frequency of glutamatergic EPSCs, in keeping with the increased density of glutamatergic terminals (Figure 4, also see below). ${ }^{44,52,53}$

Since GABAergic interneurons also degenerate, inhibitory currents were also expected to be affected. Earlier studies suggested that a reduction in GABAergic inhibition precedes the initiation of ongoing seizures by the epileptic circuit. ${ }^{54,55}$ Recordings made more recently from a variety of interneurons and the somata and dendrites of principal cells showed a massive reduction of the frequency of GABAergic PSCs in the dendrites of the principal cells, in keeping with the preferential degeneration of somatostatin-positive interneurons that innervate selectively the dendrites of pyramidal neurons. ${ }^{56,57}$ The frequency of GABAergic PSCs recorded in the somata of principal neurons was not significantly different from controls (ref?). Therefore, a dual consequence of seizures on inhibition will occur with a loss of dendritic

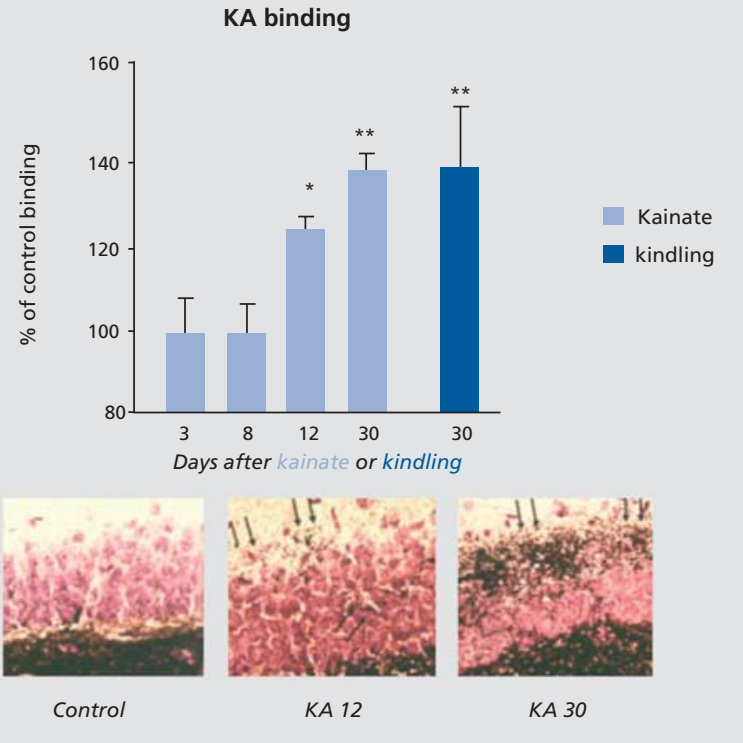

Figure 3. Increased kainate receptors binding in regions innervated by aberrant mossy fibers. There is an increased density of receptors thirty days, but not 12 days, after an inaugurating status. The latency correlates with the time needed to form novel synapses. Reproduced from ref 19: Represa A, Tremblay E, Ben-Ari Y. Kainate binding sites in the hippocampal mossy fibers: localization and plasticity. Neuroscience. 1987;20:739-748. Copyright @ Elsevier Science 1987 inhibition but a preservation of somatic inhibition. Interestingly, whereas somatic inhibition controls the generation of spikes and the output of the system, dendritic inhibition controls the currents generated by incoming EPSCs and therefore the inputs of the network..$^{58}$ Therefore, although the threshold of seizures is reduced in epileptic networks, the control of somatic activity still operates and prevents an ongoing status epilepticus. Most importantly, these observations suggest that reactive plasticity does not occur in GABAergic neurons, since the loss of dendrite inhibition is permanent. This difference between anatomic plasticity and reaction to damage may constitute a major property of networks in neurodegenerative disorders.

\section{The operation of epileptic and naive networks: similar but different}

Newly formed synapses are aberrant anatomically, but also in their operation. Thus, in controls, granule cells operate exclusively by means of AMPA (and NMDA) receptor-mediated channels. In contrast, weeks after seizures, when novel synapses have been formed, they also display pure kainate receptor-mediated EPSCs. ${ }^{59}$ Therefore, the sprouting of mossy fibers imposes the formation of aberrant kainatergic synapses in the novel targets of mossy fibers (Figure 3). ${ }^{19}$ These new synapses will have important consequences on the operation of this essential input of the hippocampal formation. Indeed, AMPA receptor-mediated EPSCs are brief, with a short latency and a time-locked precise response, therefore generating large synchronized currents. In contrast, kainite-operated currents are of small amplitude, long duration, and there are probably more opportunities for summations and alterations of synapse efficacy. To sum up, epileptic tissues have epileptic synapses that are unique to this tissue, in that they have an aberrant distribution and a signaling profile that promotes synchronized activities. This important observation implies clearly that even in the absence of seizures, "epileptic networks" operate differently from control ones. It also shows also why the link between kainate receptors, seizures, and epilepsies is instrumental.

Another illustration of the differences between naive and genuine epileptic networks comes from studies in humans: surgically removed hippocampal slices in patients suffering from TLE. Electrophysiological recordings made in these slices show that in a significant per- 


\section{Basic research}

centage of neurons, GABA has a depolarizing action because of an accumulation of chloride in neurons and thus a different gradient for chloride.$^{60}$ Indeed, GABA excites neurons in the epileptic network; this is expected to lead to major changes in the operation of the network, since inhibitory GABA plays a central role in the generation of oscillations. This property also illustrates yet another property of networks in degenerative disorders: the return to immature properties. Indeed, in all developing brain structures and animal species, there is a higher $[\mathrm{Cl}]_{\mathrm{i}}$, a property that appears to have been preserved throughout evolution. ${ }^{61,62}$ The consequence is that GABA excites immature neurons, generating sodium and calcium action potentials and producing a large calcium influx that underlies the trophic actions of GABA on developing neurons. ${ }^{63}$ There are several indications that after insults of different types, the neurons recuperate or return to their immature situation, at least as far as some signals are concerned, with the expression of various factors only found during development: "epileptogenesis recapitulates ontogenesis." These effects are due to a loss of a chloride cotransporter that acts to remove chloride from neurons. ${ }^{6466}$ Here again, the genuinely epileptic tissue has unique features not found in naive networks.

\section{Anoxic insults lead to similar post-traumatic alterations}

Reactive plasticity is not restricted to epilepsies. Indeed, it has long been recognized that ischemic insult augments the occurrence of seizures and late-onset epilepsy in humans and in animal models. ${ }^{67-69} \mathrm{~A}$ remodeling of neuronal networks also often follows the cell loss produced in CA1 pyramidal neurons after a four-vessel occlusion model..$^{70,71}$ The damage includes various GABAergic interneurons, and is associated with long-term hyperexcitability. ${ }^{53,67}$ Electrophysiological recordings of CA3 pyramidal neurons suggest that important morphofunctional reorganization has occurred, and that this is irreversible. ${ }^{26}$ Sprouting of mossy fibers has also been documented after ischemic insults, ${ }^{67}$ as well as an increased glutamatergic activity manifested by a dramatic enhancement of both the frequency of spontaneous glutamatergic EPSCs and that of miniature synaptic currents, suggesting an enhanced quantal release of glutamate. Therefore, cell loss produces massive modifications of the entire circuit, including neurons that are afferent to the damage and are associated with reorganization of net- works. These alterations may then lead to hyperactivity and seizures in the postischemic network, in keeping with the extensive clinical data suggesting postischemic hyperactivity.

\section{General implications of these observations}

The first implication of these observations is that seizures beget seizures. This is not acknowledged by many clinicians, primarily concerning temporal lobe seizures, since surgery often alleviates the ongoing seizures. Had alterations occurred, and if seizures begot seizures, then this would not be the case. However, it may be worth stressing that antiepileptic regimens are usually pursued after successful surgery; this is not readily compatible with a completely focal origin and restriction of the events. In addition, the removal in successful operations of large samples of the presumed focus may reflect the need to remove generators other than the identified focus, possibly because of generalization of seizures and alterations of sites distal to the focus. In other terms, we do not know at present whether the morphological substrate of the focus corresponds exactly to the electrical pacemaker cell assembly. I suggest that this is not the case, and that an ensemble of neurons outside the focus - in the vicinity of, or in distal regions connected to the focus - contribute to the damage and the seizures. However, additional experiments are clearly needed to clarify how many seizures lead to synapse reorganizations, and how this contributes to the formation of distal independent pacemaker cell assemblies (see also below). We need to compare the extent of the damage after a few seizures to that observed after a long period of ongoing seizures. My predictions are that these will differ significantly.

The second implication is that epileptic networks may well operate differently from naive ones, independently of the epileptogenicity. Thus, if aberrant synapses operate with different receptors, the generation of behaviorally relevant oscillations by the network will be affected. The kinetics of epileptic kainite-mediated synaptic currents is much longer than the naive AMPA currents, and thus the generation of high-frequency oscillations and the integrative properties are expected to be affected. Since epileptic networks use similar ensembles to those that generate important integrative functions, they are expected to impact these functions. In keeping with this, place cells operate differently in naive hippocampi and in epileptic ones. ${ }^{72}$ 
The third implication is that reactive plasticity should be taken more into account in our understanding of epilepsies, and possibly also neurodegenerative disorders. If synapses reorganize, new ones are formed, and a fortiori if these operate by different receptors and intracellular signals, then it may be worth using genuine epileptic networks to understand the underlying mechanisms and develop new antiepileptic drugs and regimens. Using a naive network that seizes acutely under the influence of a convulsive agent is to a large extent irrelevant. This approach, which is by far the most used to study basic mechanisms of epilepsies and develop new drugs, simply does not take into account the salient feature of genuine epilepsies, namely the aberrant synapses and signals as well as the unique networks formed a few weeks after the inaugurating event. Stated differently, it is important to study the chronic aspects of genuine epilepsies and not convulsions. An anticonvulsant drug may not be an effi-

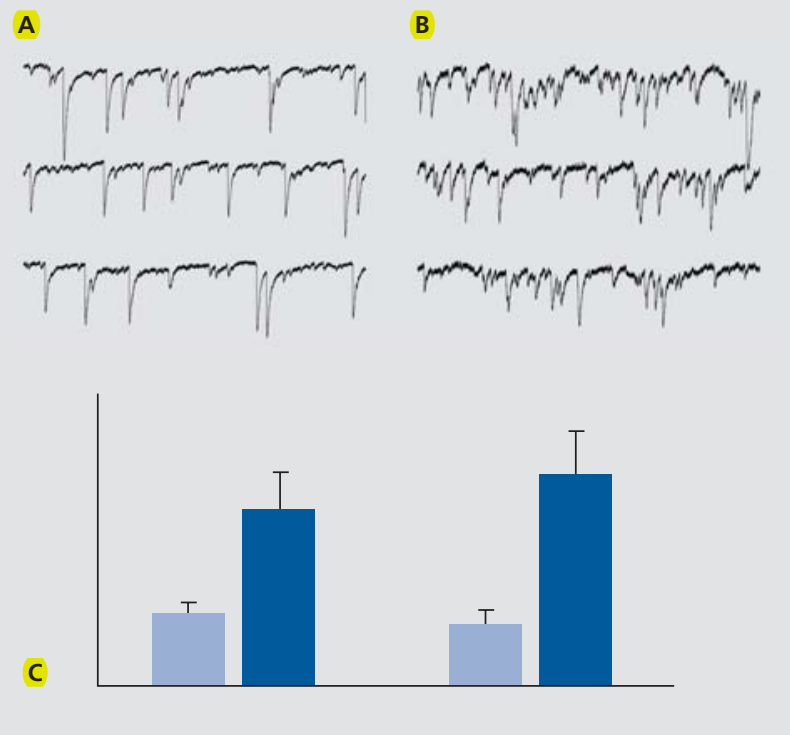

Figure 4. Enhanced glutamatergic activity in epileptic hippocampus weeks after the inaugurating event. Slices were prepared from rats 4 weeks after the status produced by a single injection of pilocarpine. Note the considerable increase of spontaneous glutamatergic activity in the epileptic hippocampus (right side) versus a control slice (left). The bottom left column illustrates the increase quantitatively (in frequency of glutamate EPSCs). The right columns show a similar increase in the miniature PSCS recorded after applications of tetrodoxin (TX) to block activitydependent currents. This suggests a long-lasting increase in quantal release of transmitter in the epileptic network. ${ }^{53}$ EPSCS, excitatory postsynaptic currents; PSCs, postsynaptic currents cient antiepileptic one. The following section illustrates this for the developing brain, which operates differently from the adult brain, yet still provides interesting elements for the debate.

\section{In the developing brain, seizures also beget seizures, but differently}

Do seizures also beget seizures in the developing brain? This is important in view of the extensive experimental data suggesting that immature neurons are more resistant to insults in terms of neuronal cell loss than adult ones. Thus, anoxic episodes require much longer durations and severity to produce cell loss early in life, in contrast to adults. ${ }^{73,74}$ Also, administration of kainate to pups until the end of the second postnatal week triggers seizures but no brain damage, and little if any apparent signs of damage. ${ }^{27}$ Therefore, a long-lasting status epilepticus can be generated in pups without neuronal damage and reactive plasticity. Yet, these seizures can lead to long-lasting consequences as shown by a lower threshold

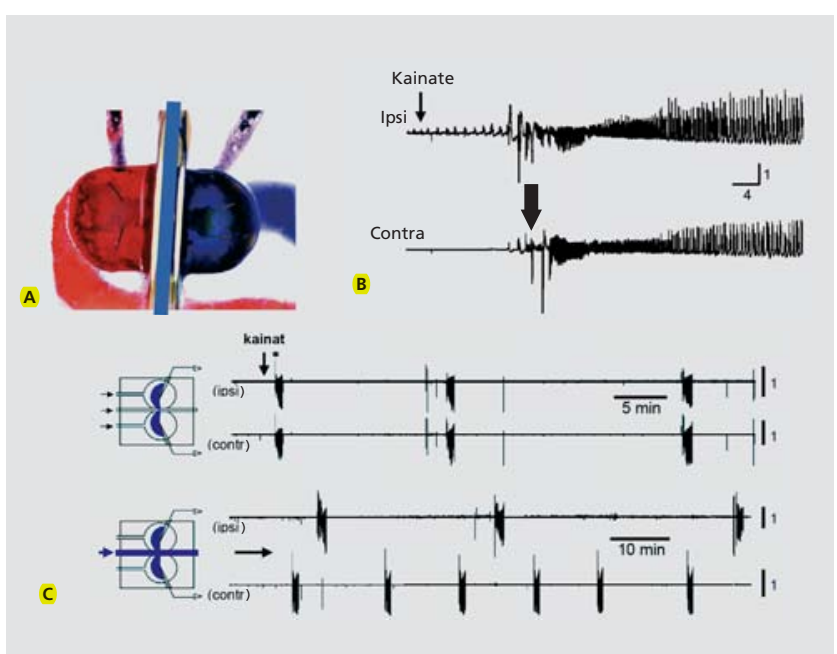

Figure 5. Seizures beget seizures in the immature hippocampus. A triple chamber is used (top left) with three compartments that accommodate each intact hippocampus and the connecting commissural connections. When the powerful convulsive agent kainate is applied, epileptiform activities are generated in the treated side and propagate rapidly to the naive side (top left). After repeated applications and seizure propagation to the naive side, tetrodoxin (TTX) a blocker of action potentials and of the propagation of seizures, was applied to the commissural chamber and effectively blocked seizures. Note (bottom part) that seizures were generated spontaneously by the naive hippocampus after disconnection form the treated side: there is formation of an epileptogenic mirror focus. ${ }^{76}$ 


\section{Basic research}

for seizure generation and major alterations of several intrinsic excitability in adults..$^{75} \mathrm{~A}$ parsimonious explanation for this paradox is that seizures in immature networks produce their long-lasting consequences by different mechanisms than in adults, and notably without producing damage, but rather by altering activity and developmental programs.

We developed a unique in vitro preparation to determine the consequences of seizures on immature networks (Figure 5). ${ }^{76}$ The two intact hippocampi are dissected intact from immature rodent brains and placed in a three-chamber compartments in which each chamber can accommodate one hippocampus and the commissural interhemispheric connections. ${ }^{77,78}$ Applications of a convulsant agent to one hippocampus generated seizures that propagated to the other hippocampus. After one seizure, interruption of the propagation does not transform the naive side to an epileptic one that generates spontaneous seizures. In contrast, after recurrent seizures, ${ }^{6-10}$ the naive side generates seizures when disconnected from the treated hippocampus; recurrent seizures have formed an epileptogenic mirror focus (Figure 5). Using this preparation, it is possible to determine the conditions needed to form a mirror focus and those that define an epileptic network. It was found that only seizures that include high-frequency oscillations (HFOs, above $40 \mathrm{~Hz}$ ) transform a naive network into an epileptic one; lower frequency events can occur with little consequences. The conditions required to generate HFOs include operative NMDA receptors, since applications of an antagonist of these receptors to the naive side blocked the HFO components of the propagated seizures and prevented the formation of a mirror focus. ${ }^{79,80}$ Since NMDA receptors play an important role in triggering persistent changes of synaptic efficacy, these observations illustrate the concept of pathological changes of synaptic efficacy that rely on mechanisms identified to play a role in physiological integrative and memory processes. In other words, the formation of epileptogenic foci occurs in regions known to play an active role in plasticity, and relies on alterations of synaptic efficacy triggered by HFO components that are constitutive of inaugurating seizures.

In further relevance to the abovementioned issues, recordings in the established mirror focus show a stable increase in $[\mathrm{Cl}]_{\mathrm{i}}$, and depolarizing and excitatory actions of GABA. ${ }^{79}$ Therefore, recurrent seizures trigger a persistent accumulation of chloride in neurons, in keeping with the unique properties of epileptogenic networks and the importance of taking into account the differences between acute seizures and epilepsies.

\section{Conclusion}

In conclusion, these observations call for a re-examination of the study of epilepsies and other lifelong neurological disorders by examining the properties of chronically affected neurons and networks, rather than acute models. The importance of reactive plasticity and the unique features and signals of pathological networks suggest that alterations that occur during the "maturation" process of the focus contribute to the disorder, and must be taken into account in its treatment. The nervous system is extremely "plastic" and reacts to a lesion or a disorder by forming new synapses and new signaling cascades that impact the operation of the structure in ongoing conditions, independently of the pathological events.

\section{REFERENCES}

1. Freund T, Buzsaki G. Interneurons of the hippocampus. Hippocampus. 1996;6:345-470.

2. Ylinen A, Bragin A, Nadasdy Z, et al. Sharp wave associated high-frequency oscillation $(200 \mathrm{~Hz})$ in the intact hippocampus: network and intracellular mechanisms. J Neurosci. 1995;15:30-46.

3. Buzsaki G. Rhythms of the Brain. Oxford, UK; New York, NY: Oxford University Press; 2006.

4. Khazipov R, Sirota A, Leinekugel X, Holmes GL, Ben Ari Y, Buzsaki G. Early motor activity drives spindle bursts in the developing somatosensory cortex. Nature. 2004;432:758-761.

5. Leinekugel X, Khazipov R, Cannon R, Hirase H, Ben Ari Y, Buzsaki G. Correlated bursts of activity in the neonatal hippocampus in vivo. Science. 2002;296:2049-2052.

6. Bartos M, Vida I, Frotscher M, et al. Fast synaptic inhibition promotes synchronized gamma oscillations in hippocampal interneuron networks. Proc Natl Acad Sci U S A. 2002;99:13222-13227.

7. Fuentealba $P$, Steriade $M$. The reticular nucleus revisited: intrinsic and network properties of a thalamic pacemaker. Prog Neurobiol. 2005;75:125141.

8. Destexhe A, Contreras D, Steriade M. Mechanisms underlying the synchronizing action of corticothalamic feedback through inhibition of thalamic relay cells. J Neurophysiol. 1998;79:999-1016.

9. Cunningham MO, Whittington MA, Bibbig A, et al. A role for fast rhythmic bursting neurons in cortical gamma oscillations in vitro. Proc Nat/ Acad Sci U S A. 2004;101:7152-7157.

10. Isomura $Y$, Sirota A, Ozen $S$, et al. Integration and segregation of activity in entorhinal-hippocampal subregions by neocortical slow oscillations. Neuron. 2006;52:871-882. 


\section{Epilepsias y plasticidad neuronal: ¿para mejor o para peor?}

Numerosas investigaciones experimentales han confirmado que "las convulsiones engendran convulsiones". En adultos, las convulsiones límbicas producen pérdida de células, proceso que es seguido por la formación de nuevas sinapsis excitatorias, las cuales contribuyen a generar nuevas convulsiones. La señal gatillo es un aumento de la eficacia sináptica, seguida de una cascada molecular que genera brotes axonales. Las nuevas sinapsis son aberrantes $y$ se forman en regiones que en los sujetos controles no presentan este tipo de sinapsis. Ellas también incluyen receptores que tampoco están presentes en los controles, y esto facilita la generación de convulsiones. Por lo tanto, una forma aberrante de plasticidad neuronal reactiva provee un sustrato para tener convulsiones como una forma de secuelas a largo plazo. Estos acontecimientos tendrán un importante impacto ya que ocurren en estructuras cerebrales involucradas en funciones de integración y mnémicas. La plasticidad reactiva está documentada por otros daños y trastornos, y puede ser la base de la progresión a largo plazo de trastornos neurodegenerativos.

11. Bliss TVP, Lancaster $B$, Wheal HV. Long-term potentiation in commissural and Schaffer projections to hippocampal CA1 cells: an in vivo study in the rat. J Physiol. 1983;341:617-626.

12. Bliss TVP, Collingridge GL. A synaptic model of memory: long-term potentiation in the hippocampus. Nature. 1993;361:31-39.

13. Malenka RC, Kauer JA, Zucker RS, Nicoll RA. Postsynaptic calcium is sufficient for potentiation of hippocampal synaptic transmission. Science. 1988;242:81-84.

14. Nicoll RA, Malenka RC. Expression mechanisms underlying NMDA receptor-dependent long-term potentiation. Ann N Y Acad Sci. 1999;868:515525.

15. Lothman EW, Bertram EH, III. Epileptogenic effects of status epilepticus. Epilepsia. 1993;34 (suppl 1):S59-S70.

16. Ben Ari Y. Limbic seizure and brain damage produced by kainic acid: mechanisms and relevance to human temporal lobe epilepsy. Neuroscience. 1985;14:375-403.

17. Ben Ari Y, Cossart R. Kainate, a double agent that generates seizures: two decades of progress. Trends Neurosci. 2000;23:580-587.

18. Ben Ari Y, Holmes GL. Effects of seizures on developmental processes in the immature brain. Lancet Neurol. 2006;5:1055-1063.

19. Represa A, Tremblay E, Ben-Ari Y. Kainate binding sites in the hippocampal mossy fibers: localization and plasticity. Neuroscience. 1987;20:739-748.
20. Ben-Ari Y, Gho M. Long-lasting modification of the synaptic properties of rat CA3 hippocampal neurones induced by kainaic acid. J Physiol. 1988;404:365-384.

21. Nowak L, Bregestovski P, Ascher P, Herbet A, Prochiantz A. Magnesium gates glutamate-activated channels in mouse central neurones. Nature. 1984;307:462-465.

22. Malenka RC. Synaptic plasticity in the hippocampus: LTP and LTD. Cell. 1994;78:535-538.

23. Aniksztejn L, Ben-Ari Y. Expression of LTP by AMPA and/or NMDA receptors is determined by the extent of NMDA receptors activation during the tetanus. J Neurophysiol. 1995;74:2349-2357.

24. Ben-Ari Y, Aniksztejn L. A united theory for the multiple forms of LTP. Trends Neurosci. 1995;18:519-520.

25. Crepel V, Hammond C, Chinestra P, Diabira D, Ben-Ari Y. A selective LTP of NMDA receptor-mediated currents induced by anoxia in CA1 hippocampal neurons. J Neurophysiol. 1993;70:2045-2055.

26. Crepel V, Congar P, Aniksztejn L, Gozlan H, Hammond C, Ben Ari Y. Synaptic plasticity in ischemia: role of NMDA receptors. Prog Brain Res. 1998; 116:273-85:273-285.

27. Ben-Ari Y. Limbic seizure and brain damage produced by kainic acid: mechanisms and relevance to human temporal lobe epilepsy. Neuroscience. $1985 ; 14: 375-403$. 


\section{Basic research}

28. Lerma J, Morales M, Vicente MA, Herreras O. Glutamate receptors of the kainate type and synaptic transmission. Trends Neurosci. 1997;20:9-12.

29. Cossart R, Epsztein J, Tyzio R, et al. Quantal release of glutamate generates pure kainate and mixed AMPA/kainate EPSCs in hippocampal neurons. Neuron. 2002;35:147-159.

30. Castillo PE, Malenka RC, Nicoll RA. Kainate receptors mediate a slow postsynaptic current in hippocampal CA3 neurons. Nature. 1997;388:182186.

31. Cossart R, Esclapez M, Hirsch JC, Bernard C, Ben-Ari Y. Activation of GluR5 receptors in interneurons increases tonic GABAergic inhibition of pyramidal neurons. Nat Neurosci. 1998;1:470-478.

32. Coussen $\mathrm{F}$, Mulle $\mathrm{C}$. Kainate receptor-interacting proteins and membrane trafficking. Biochem Soc Trans. 2006;34:927-930.

33. Hollmann M, O'Shea-Greenfield A, Rogers SW, Heinemann S. Cloning by functional expression of a member of the glutamate receptor family. Nature. 1989;342:643-648.

34. Bettler B, Egebjerg J, Sharma G, et al. Cloning of a putative glutamate receptor: a low affinity kainate-binding subunit. Neuron. 1992;8:257-265.

35. Mulle C, Sailer A, Perez-Otano I, Dickinson-Anson H, et al. Altered synaptic physiology and reduced susceptibility to kainate-induced seizures in GluR6-deficient mice. Nature. 1998;392:601-605.

36. Gaïarsa JL, Zagrean L, Ben-Ari Y. Neonatal irradiation prevents the formation of hippocampal mossy fibers and the epileptic action of kainate on rat CA3 pyramidal neurons. J Neurophysiol. 1994;71.

37. Cossart R, Esclapez M, Hirsch JC, Bernard C, Ben Ari Y. GluR5 kainate receptor activation in interneurons increases tonic inhibition of pyramidal cells. Nat Neurosci. 1998;1:470-478.

38. Khalilov I, Hirsch J, Cossart R, Ben Ari Y. Paradoxical anti-epileptic effects of a GluR5 agonist of kainate receptors. J Neurophysiol. 2002;88:523-527.

39. Lothman EW, Bertram EH3, Stringer JL. Functional anatomy of hippocampal seizures. Prog Neurobiol. 1991;37:1-82.

40. Ben-Ari Y, Tremblay E, Ottersen OP, Meldrum BS. The role of epileptic activity in hippocampal and 'remote' cerebral lesions induced by kainic acid. Brain Res. 1980;191:79-97.

41. Nadler JV, Perry BW, Cotman CW. Selective reinnervation of hippocampal area CA1 and the fascia dentata after destruction of CA3-CA4 afferents with kainic acid. Brain Res. 1980;182:1-9.

42. Nadler JV. Minireview. Kainic acid as a tool for the study of temporal lobe epilepsy. Life Sci. 1981;29:2031-2042.

43. Lothman EW. Basic mechanisms of the epilepsies. Curr Opin Neurol Neurosurg. 1992;5:216-223.

44. Esclapez M, Hirsch JC, Ben Ari Y, Bernard C. Newly formed excitatory pathways provide a substrate for hyperexcitability in experimental temporal lobe epilepsy. J Comp Neurol. 1999;408:449-460.

45. Represa A, Pollard H, Moreau J, Ghilini G, Khrestchatisky M, Ben-Ari Y. Mossy fiber sprouting in epileptic rats is associated with a transient increased expression of alpha-tubulin. Neurosci Lett. 1993;156:149-152. 46. Represa A, Tremblay E, Ben-Ari Y. Sprouting of mossy fibers in the hippocampus of epileptic human and rat. Adv Exp Med Biol. 1990;268:41924:419-424.

47. Represa A, Jorquera I, Le Gal La Salle G, Ben-Ari Y. Epilepsy induced collateral sprouting of hippocampal mossy fibers: does it induce the development of ectopic synapses with granule cell dendrites? Hippocampus. 1993;3:257-268.

48. Nedivi E, Hevroni D, Naot D, Israeli D, Citri Y. Numerous candidate plasticity-related genes revealed by differential cDNA cloning. Nature. 1993;363:718-722.

49. Pollard H, Bugra K, Khrestchatisky M, Represa A, Ben-Ari Y. Seizureinduced molecular changes, sprouting and synaptogenesis of hippocampal mossy fibers. Epilepsy Res Suppl. 1996;12:355-363.

50. Ben-Ari Y, Represa A. Brief seizure episodes induce long-term potentiation and mossy fibre sprouting in the hippocampus. Trends Neurosci. 1990;13:312-318.

51. Khrestchatisky M, Ferhat L, Charton G, et al. Molecular correlates between reactive and developmental plasticity in the rat hippocampus. $J$ Neurobiol. 1995;26:426-436.

52. Bernard C, Cossart R, Hirsch J, Esclapez M, Ben-Ari Y. What is GABAergic inhibition? How is it modified in epilepsy? Epilepsia. 2000;41:90-95.
53. Epsztein J, Milh M, Bihi RI, et al. Ongoing epileptiform activity in the post-ischemic hippocampus is associated with a permanent shift of the excitatory-inhibitory synaptic balance in CA3 pyramidal neurons. J Neurosci. 2006;26:7082-7092.

54. Kapur J, Michelson HB, Buterbaugh GG, Lothman EW. Evidence for a chronic loss of inhibition in the hippocampus after kindling: electrophysiological studies. Epilepsy Res. 1989;4:90-99.

55. Mody I, Otis TS, Staley KJ, Kohr G. The balance between excitation and inhibition in dentate granule cells and its role in epilepsy. Epilepsy Res Suppl. 1992:9:331-339.

56. Hirsch J, Agassandian C, Merchan-Pérez A, et al. Deficit in quantal release of GABA in experimental models of temporal lobe epilepsy. Nat Neurosci. 1999;2:499-500.

57. Cossart R, Denocourt C, Hirsch J, Merchan-Perez A, et al. Dendritic but not somatic GABAergic inhibition is decreased in experimental epilepsy. Nat Neurosci. 2001;4:52-62.

58. Miles R, Toth K, Gulyas Al, Hajos N, Freund TF. Differences between somatic and dendritic inhibition in the hippocampus. Neuron. 1996;16:815823.

59. Epsztein J, Represa A, Jorquera I, Ben Ari Y, Crepel V. Recurrent mossy fibers establish aberrant kainate receptor-operated synapses on granule cells from epileptic rats. J Neurosci. 2005;25:8229-8239.

60. Cohen I, Navarro V, Clemenceau S, Baulac M, Miles R. On the origin of interictal activity in human temporal lobe epilepsy in vitro. Science. 2002;298:1418

61. Benari Y, Cherubini E, Corradetti R, Gaiarsa JL. Giant synaptic potentials in immature rat Ca3 hippocampal-neurons. J Physiol. 1989;416:303325.

62. Ben Ari Y. Excitatory actions of GABA during development: The nature of the nurture. Nat Rev Neurosci. 2002;3:728-739.

63. Represa A, Ben Ari Y. Trophic actions of GABA on neuronal development. Trends Neurosci. 2005;28:278-283.

64. Rivera C, Voipio J, Payne JA, et al. The $\mathrm{K}+/ \mathrm{Cl}$ - co-transporter $\mathrm{KCC} 2$ renders GABA hyperpolarizing during neuronal maturation. Nature. 1999;397:251-255.

65. Rivera C, Voipio J, Thomas-Crusells J, et al. Mechanism of activitydependent downregulation of the neuron-specific $\mathrm{K}-\mathrm{Cl}$ cotransporter KCC2. J Neurosci. 2004;24:4683-4691.

66. Fiumelli H, Cancedda L, Poo MM. Modulation of GABAergic transmission by activity via postsynaptic $\mathrm{Ca} 2+$-dependent regulation of $\mathrm{KCC} 2$ function. Neuron. 2005;48:773-786.

67. Congar P, Gaiarsa JL, Popovici T, Ben Ari Y, Crepel V. Permanent reduction of seizure threshold in post-ischemic CA3 pyramidal neurons. J Neurophysiol. 2000;83:2040-2046.

68. Lossius MI, Ronning OM, Slapo GD, Mowinckel P, Gjerstad L. Poststroke epilepsy: occurrence and predictors - a long-term prospective controlled study (Akershus stroke study). Epilepsia. 2005;46:1246-1251.

69. Cocito L, Favale E, Reni L. Epileptic seizures in cerebral arterial occlusive disease. Stroke. 1982;13:189-195.

70. Pulsinelli WA. Selective neuronal vulnerability: morphological and molecular characteristics. Prog Brain Res. 1985;63:29-37.

71. Schmidt-Kastner R, Freund TF. Selective vulnerability of the hippocampus in brain ischemia. Neuroscience. 1991;40:599-636.

72. Shatskikh TN, Raghavendra M, Zhao Q, Cui Z, Holmes GL. Electrical induction of spikes in the hippocampus impairs recognition capacity and spatial memory in rats. Epilepsy Behav. 2006;9:549-556.

73. Cherubini E, Ben-Ari Y, Krnjevic K. Anoxia produces smaller changes in synaptic transmission, membrane potential, and input resistance in immature rat hippocampus. J Neurophysiol. 1989;62:882-895.

74. Crepel V, Krnjevic K, Ben-Ari Y. Developmental and regional differences in the vulnerability of rat hippocampal slices to lack of glucose. Neuroscience. 1992;47:579-587.

75. Villeneuve N, Ben-Ari Y, Holmes GL, Gaïarsa JL. Neonatal seizures induced persistent changes in intrinsic properties of CA1 rat hippocampal cells. Ann Neurol. 2000;47:729-738.

76. Khalilov I, Holmes GL, Ben Ari Y. In vitro formation of a secondary epileptogenic mirror focus by interhippocampal propagation of seizures. Nat Neurosci. 2003;6:1079-1085. 
77. Khazipov R, Desfreres L, Khalilov I, Ben-Ari Y. Three-independent-compartment chamber to study in vitro commissural synapses. J Neurophysiol. 1999;81:921-924.

78. Khalilov I, Esclapez M, Medina I, et al. A novel in vitro preparation: the intact hippocampal formation. Neuron. 1997;19:743-749.
79. Khalilov I, Van Quyen M, Gozlan H, Ben Ari Y. Epileptogenic actions of GABA and fast oscillations in the developing hippocampus. Neuron. 2005; $48: 787-796$

80. Le Van QM, Khalilov I, Ben Ari Y. The dark side of high-frequency oscillations in the developing brain. Trends Neurosci. 2006;29:419-427. 